Юдіна Н. В.

канд. економ. наук, дочент ORCID ID: 0000-0002-1730-9341

Національний технічний університет Украӥни «Київський політехнічний інститут імені Ігоря Сікорського»

\title{
ДОСЛІДЖЕННЯ СПОЖИВЧИХ МОТИВАЦІЙ НА ІННОВАЦІЙНУ ТЕХНОЛОГІЮ ОЧИЩЕННЯ ВОДИ
}

\section{ИССЛЕДОВАНИЯ ПОТРЕБИТЕЛЬСКИХ МОТИВАЦИЙ НА ИННОВАЦИОННУЮ ТЕХНОЛОГИЮ ОЧИСТКИ ВОДЫ}

\section{RESEARCH OF CONSUMERS' MOTIVATIONS ON INNOVATIVE WATER TREATMENT TECHNOLOGY}

У статті наведені результати маркетингового дослідження споживчих мотиваџій на інновачійну технологію очищення води, щзо була покладена в основу украйнського стартапа фільтрувального обладнання. Підкреслено актуальність подібних досліджень інновачійних ринків для масштабування їх результатів на інші схожі і аналогічні ринки $з$ метою виведення на них стартапів особливо в умовах економічних криз. Докладно розглянуто проблеми $і$ можливості ринку фільтрувального обладнання на прикладі результатів опитування київських домогосподарств. Показано зсув стереотипів у сприйнятті якості вітчизняних товарів порівняно із імпортованими у бік суттєвого покращення, за щу споживачі готові платити більще. Продемонстрована різниця у споживчих мотиваціях київських домогосподарств на фільтрувальне обладнання. Результати дослідження, щзо наведені в статі можуть бути використані при написанні наукових праць, статей на тематику інноваційного маркетингу, маркетингу стартаппроектів, просування інновачійних технологій очищення води на ринку фільтрувального обладнання України, а також при розробияі стартапів, щзо виводяться на аналогічні $i$ схожі ринки Украӥни.

Ключові слова: ринок фільтрувального обладнання, стартап, інновачї̈, маркетинг

Results of marketing researches of consumers' motivations on an innovative water treatment technology were conducted for the Ukrainian startup of water treatment equipments that was based on this technology. It was highlighted that such researches of innovative markets are important for their scaling in other similar or analogical markets and innovative startups to be entered in those markets particularly in the economic crisis. Threats and opportunities of the water treatment market were studied on the basis of an example of the Kyiv household survey results. A shift of consumers' stereotypes about quality of domestic native producers' products was shown in order of its improving. It also means that consumes are really ready to pay more for it. Differences of the Kyiv householders' motivations on water treatment equipments were demonstrated in the article. The results of the marketing researches presented in the article can be used for scientific writings, articles on the innovative marketing, marketing of startupsprojects, promotion of water treatment technologies in the Ukrainian market of the water treatment equipments and other innovative technologies, for developing of startups that are entered in similar or analogical markets in Ukraine.

Key words: water treatment market, startup, innovations, marketing 
В статье приведены результаты маркетинговых исследований потребительских мотиваций на инновачионную технологию очистки воды, которая была положена в основу украинского стартапа фильтровального оборудования. Подчеркнута актуальность подобных исследований инноваџионных рынков для масштабирования их результатов на другие схожсе и аналогичные рынки с иелью выведения на них стартапов особенно в условиях экономических кризисов. Подробно рассмотрены проблемы и возможности рынка фильтровального оборудования на примере результатов опроса киевских домохозяйств. Показано смещение стереотипов восприятия качества отечественных товаров по сравнению с импортными в сторону существенного улучшения, за что потребители готовы платить больше. Продемонстрирована разница в потребительских мотивациях киевских домохозяйств на фильтровальное оборудование. Результатьл исследований, которые приведены в статье могут быть использованы при написании научных работ, статей по тематике инновачионного маркетинга, маркетинга стартаппроектов, продвижения инновачионных технологий очистки воды на рынке фильтровального оборудования Украины, а также при разработке стартапов, которые выводятся на аналогичные и схожие рынки Украины.

Ключевые слова: рынок фильтровального оборудования, стартап, инновации, маркетинг

Вступ. Одним 3 актуальних питань виведення на ринок будь-якої інноваційної технології, що передбачає створення стартап-проекту, $\epsilon$ розуміння розробниками споживчих мотивації на відповідні інноваційні рішення. Адже розроблення стартапу передбачає чітке розуміння того, наскільки пропоновані інноваційні рішення будуть сприйняті споживачами та що необхідно для цього зробити. Чітка відповідність пропонованої технології психологічному рівню вимог і очікувань споживачів сприятиме формуванню довготривалих благоприємних стосунків із споживачами, що $є$ запорукою довгострокового успіху підприємств.

3 цією проблематикою стикається більшість розробників-науковців, оскільки складно відшукати доступну маркетингову інформацію для принципово інноваційних рішень. Одним зі способів подолання цієї проблеми можуть слугувати результати маркетингових досліджень, проведених на схожих чи аналогічних ринках, що робить такі данні надзвичайно актуальними в умовах економічних криз [1;2].

Одному з таких маркетингових досліджень споживчих мотивацій на ринку фільтрувального обладнання і присвячена дана стаття, результати якої можуть бути використані у якості аналогії також і на інших ринках, на які будуть виводитися схожі інноваційні стартапи. Українськими вченими була розроблена інноваційна технологія ефективного вилучення гумусових речовин з води для очищення питної води [3-5], що було покладено в основу їх стартапа 3 виведення фільтрувального обладнання на український ринок. Сутність інноваційної ідеї, запропонованої розробниками, полягала у тому, що найбільш ефективне і доцільне вирішення проблем очищення питної води є застосування спеціальних смол, що використовуються для глибокого 
доочищення води від гумусових речовин. Гумусові речовини являють собою продукт розпаду білків та інших біополімерів рослинного та тваринного походження. У чистому вигляді гумусові речовини нешкідливі та навіть застосовні у фармакології. Однак при хлоруванні води гумусові речовини окислюються до шкідливих похідних. Крім того, гумусові речовини здатні сорбувати шкідливі речовини з природних вод і переносити їх у питну воду. Враховуючи, що розмір молекул гумусових речовин може коливатися у широкому інтервалі, вибір сорбенту повинен відповідати переважаючому розміру молекул гумусових речовин, що присутні у воді, яка потрапляє на очищення. Запропонована інноваційна технологія очищення води грунтувалася на знаходженні і застосуванні певної комбінації сорбентів різної пористої структури у залежності від характеру і складу забруднення відповідної води, яка потрапляє на очищення. Це передбачало можливість виведення на український ринок нового фільтрувального обладнання, яке розроблено із використанням цієї інноваційної технології.

Постановка завдання. Маркетингове обгрунтування доцільності виведення на вітчизняний ринок українського стартапа фільтрувального обладнання, що грунтувався на інноваційній технології очищення води від гумусових речовин.

Методологія. Методологічною основою є фундаментальні теоретичні положення економічної теорії та маркетингу; загальнонаукові методи, зокрема системного аналізу, синтезу, наукової абстракції, опитування, анкетування, аналіз статистичних даних.

Результати дослідження. 3 метою перевірки доцільності виведення на український ринок нового фільтрувального обладнання нами було проведено маркетингове дослідження, яке складалося 3 кабінетних i польових досліджень. У результаті попередньо проведеного кабінетного дослідження маркетингового середовища найбільш впливовими виявилися наступні групи факторів. Позитивним був вплив природних факторів, який полягав у тому, що вода в різних районах Києва через існування Дніпровського та Деснянського водозаборів забруднена різними речовинами по-різному. Це дозволило виокремити гіпотезу диференційованого попиту на інноваційну технологію диференційованого очищення води в залежності від географії помешкань потенційних споживачів. Позитивний вплив економічних факторів полягав у досить повільному оновленні технологічного обладнання централізованого водопостачання у м. Києві. Цей фактор сприяв підвищенню попиту на додатковий ступінь очищення води від різноманітних механічних домішок, гумусових речовин та іонів жорсткості. Соціо-культурні фактори підсилювали вплив вище розглянутих економічних факторів. Київ належить до історичних центрів, де перекопування 3 метою заміни застарілого обладнання для водопостачання також гальмувалося необхідністю збереження 
історичних пам'яток міста Київ. Позитивний вплив науково-технічних факторів полягав у доступі розробників до баз даних новітніх розробок у галузі хімічної очистки води, створених вченими україно-німецьких сумісних проектів. Негативний вплив споживачів і конкурентів на виведення стартапа полягав у тому, що біля 64\% потенційних кінцевих споживачів вже встигли придбати фільтрувальне обладнання конкурентів та 3 малою вірогідністю знехтують існуючим обладнанням заради нового. Позитивним також був факт встановлених доброзичливих стосунків розробників із постачальниками хімічних сорбентів з Німеччини, а також сумісні наукові дослідження та ексклюзивні умови постачання в Україну відповідних хімічних сорбентів.

На основі проведеного аналізу факторів маркетингового середовища було сформулювало наступну управлінську можливість: «Виведення на ринок України інноваційного обладнання для очищення води, адаптованого до складу забруднень у відповідному територіальному районі м. Київ». Для реалізації виявленої можливості було сформульовано чотири альтернативні гіпотези, які передбачалося перевірити у ході дослідження, а саме:

1. Виведення на ринок нового побутового фільтру „А”, адаптованого до складу забруднення у відповідному територіальному районі, використовуючи стратегію сегментації за територіальною ознакою.

2. Виведення на ринок нового універсального українського фільтру „А”, адаптованого до складу забруднення української води, використовуючи стратегію масового маркетингу.

3. Виведення на ринок нового картриджу „А” для вже встановленого фільтрувального обладнання марки „В”, адаптованого до складу забруднення у відповідному територіальному районі, використовуючи стратегію сегментації за територіальною ознакою.

4. Виведення на ринок нового універсального українського картриджу „А” для вже встановленого фільтрувального обладнання марки „В”, адаптованого до складу забруднення української води, використовуючи стратегію масового маркетингу.

Для визначення доцільності запровадження підприємством обраних альтернативних варіантів реалізації управлінської можливості необхідно було отримати достовірну маркетингову інформацію. Для цього було прийнято рішення щодо проведення польового маркетингового дослідження методом опитування київських домогосподарств, використовуючи для цього квотовану вибірку у відповідності із кількістю київського населення у кожному 3 виділених чотирьох районів міста у залежності від типу водозабору та ступеню забруднення води гумусовими речовинами (за результатами попередньо отриманого хімічного аналізу проб води у цих районах). Аналіз результатів проведеного опитування дозволив зробити наступні загальні висновки та запропонувати певні рекомендації. 
Перш за все, кияни не мали чіткого розуміння сутності та переліку шкідливих речовин, від яких треба очищувати воду, що свідчило про низьку культуру споживання питної води. Опитані експерти, у ролі яких виступали продавці та представники конкуруючих компаній на ринку фільтрувального обладнання, зазначали, що розуміння споживачами якості водопровідної води лімітується декількома характеристиками води, і всі вони для споживача дуже відносні. Це свідчило про необхідність налагодження програм поінформування киян про якість води у їх помешканнях.

При цьому, з тим, що воду все ж треба очищувати погодилися $91 \%$ опитаних київських домогосподарств. У якості основних шляхів вирішення проблем питної води залишалися кип'ятіння $(66,7$ \%) та артезіанські свердловини (34\%). Біля $64 \%$ респондентів вже мали побутовий фільтр, однак лише $16 \%$ з них регулярно змінювали картридж один раз на три місяці. До вживання фасованої води схилялися 21,3\% респондентів. Виходячи 3 цих даних, при просуванні інноваційного побутового фільтру перспективним напрямом стала концепція «просто вода (можна фасованої), відфільтрованої новим фільтром».

Опитування респондентів з чотирьох різних районів міста Київ виявило присутність різниці у ставленні опитаних респондентів до якості водопровідної води, що постачається в їх помешкання. Цікаво, що $9 \%$ респондентів, які не погодились 3 актуальністю для них проблем забруднення водопровідної води у м. Київ, виявилися мешканцями районів Оболоні (ці райони за результатами хімічного аналізу проб води не потребували попереднього очищення води). Однак за сукупним аналізом результатів опитувань дослідженні окремі райони Києва, на наш погляд, не доцільно відносити до різних сегментів. Тому була підтверджена гіпотеза стратегії масового маркетингу в межах обраного цільового ринку. На противагу цьому, у різних регіонах України була підтверджена гіпотеза суттєвої різниці у мотиваціях споживачів на очищення. Це надало змогу на рівні різних регіонів України підтвердити необхідність дотримання стратегії сегментації за географічним розташуванням. Тому у подальшому для кожного з зазначених регіонів було запропоновано індивідуальний картридж, що диференційовано очищує воду від тих забруднень, що характерні для води у відповідних регіонах України.

У результаті опитування було виявлено, що респонденти розуміють, що українська вода різниться від тієї, на яку розраховані імпортні фільтри. Також простежувалась серед респондентів думка, що в залежності від району міста вода за своїм складом різна (71 \% респондентів 3 цим погодилися). Це відкривало можливість встановлення диференційованої ціни, адже споживач був згоден платити більше за якісні властивості фільтрувального обладнання. Біля 95,2 \% респондентів, які вже мали в помешканні побутовий фільтр, 
погодилися б придбати вітчизняний картридж для свого фільтру, який би враховував особливості української води. Це питання в ході опитування викликало жваву зацікавленість до такого товару. Крім того, цей факт також свідчив про зміну і формування у свідомості споживача позиції про високу якість вітчизняних товарів, що говорить про перспективу розвитку саме українського виробництва. Можлива величина надбавки до ціни на вітчизняний інноваційний картридж порівняно із імпортованими аналогами коливалася від 10,1 \% до 13,5 \%; на вітчизняний фільтр - приблизно 10-16 \%. На такі результати слід звернути особливу увагу, оскільки такі данні можуть бути масштабовані на будь-які інші товари та послуги вітчизняного виробництва.

Цікавим виявився також факт, що ціна не уявляється визначальним фактором при прийнятті рішення про покупку. Для побутового фільтру найголовнішими його характеристиками, за оцінкою як самих респондентів, так і експертів, є якість очищення (10 балів), його ресурс (9 балів) і тільки потім ціна (8 балів). Естетичні характеристики побутового обладнання також впливають на прийняття рішення (7 балів). Як бачимо, на ринку побутових фільтрів поруч 3 раціональними мотивами поведінки споживачів, а саме, мотивами гарантії та надійності, простежується вплив емоційних мотивів.

Слід звернути увагу, що конструкція інноваційного фільтру не грає визначальної ролі при прийнятті рішення про покупку - 5 балів. Також був виявлений стереотип про відносно велику вагу настільних фільтрів, причому вага, як критерій прийняття рішення про покупку, виявилася важливіше, ніж тип конструкції. Однак за ступенем споживчих уподобань саме така конструкція стала безумовним лідером (56 \%), що перевищило всі сподівання. Головною причиною невеликої частки продажу саме такої конструкції (за оцінкою експертів) був мотив економії. Тому, задачею комунікативної політики стає актуалізація мотиву довгострокового використання. Слід зазначити, що значна частина опитаних респондентів (біля $44 \%$ опитаних респондентів) взагалі не була знайома $з$ жодною маркою побутових фільтрів.

Опитані експерти зазначали, що розуміння споживача щодо якості товару дуже часто лімітується декількома параметрами, i всі вони залишаються дуже відносними. У таких випадках головним джерелом інформації та довіри частіше стають продавці. За результатами опитування, саме їх думка щодо товару з запропонованого асортименту виявляється для споживача визначальною. Так, біля $37 \%$ опитаних респондентів прислуховуються до таких порад. Окрім того, 83 \% респондентів зазначали, що їм зручніше купувати фільтри в магазинах. Отже, все більше підвищується впливовість інтегрованих маркетингових комунікацій у місцях продажу. При цьому серед шляхів пошуку інформації споживачі використовують різноманітні джерела. Значно підвищилась роль виставок та інтернет (40 \% та 
26\% відповідно). Але все свідчить про необхідність застосування значної кількості комунікативних носіїв.

При налагодженні каналів розподілу являється досить перспективним напрямком відкриття власного фірмового магазину (3 7\%). Біля $24 \%$ респондентів виявили бажання звернутися безпосередньо до виробника фільтрів, ціни якого споживачам здаються нижчими порівняно із посередниками. Але $46 \%$ опитаних надавали перевагу спеціалізованим магазинам побутової техніки чи аналогічним відділам у супермаркетах. Була виявлена недовіра $1,2 \%$ киян до мережевих “дистриб”юторів" чи розповсюджувачів через існування стереотипу ненадійності мережних компаній, які використовують інструменти мережного маркетингу: “...сьогодні він $є$, а завтра необхідно буде купувати інший фільтр, тому, що ніде нема картриджів...”. Однак, 22 \% опитаних респондентів знайомі та використовували марки фільтрів таких компаній, що свідчить про досить успішну політику розповсюдження фільтрів за допомогою мереженого маркетингу. Тому, виходячи 3 отриманих результатів найбільш перспективним являється налагодження комплексної збутової мережі.

Висновки. Таким чином, отриманні результати дослідження обгрунтували доцільність виведення на ринок нового фільтрувального обладнання у вигляді вітчизняної марки побутового фільтру глечикового типу, картридж якого адаптований до складу забруднення у відповідному територіальному районі. Наукова новизна отриманих результатів дослідження полягає у комплексному дослідженні попиту та споживчих мотивацій на інноваційну технологію очищення води. Проаналізовані результати, отримані на основі проведеного маркетингового дослідження споживчих мотивацій на інноваційний побутовий фільтр, дозволили виявити основні тенденції та мотиви споживчої поведінки київських домогосподарств, які можуть бути використані у якості аналогій і масштабовані іншими стартапами при виході на аналогічні і схожі ринки України.

Новий етап розвитку ринку фільтрувального обладнання потребує встановлення та закріплення стосунків 3 споживачами за рахунок не тільки підвищених вимог до якості та функціональних характеристик фільтрів, підвищення якості очищення води за рахунок інноваційних технологій, але й сутності інтегрованих маркетингових комунікацій, які мають чітко та зрозуміло роз'яснювати сутність інноваційної технології споживачам. Це стає можливим тільки на основі проведення грунтовних маркетингових досліджень. Вони дозволяють виявити існуючий у споживачів рівень розуміння досліджуваної проблеми, що покращує встановленню ефективних комунікацій для роз'яснення сутності запропонованих підприємством інновацій. 
Практичне значення отриманих результатів дослідження полягає у можливості їхнього застосування в розробці маркетингових і рекламних стратегій підприємствами-виробниками інноваційного фільтрувального обладнання, а також представниками інших схожих і аналогічних ринків, що допоможе їм зайняти більш вигідну позицію на сучасному українському ринку.

\section{Література:}

1. Юдіна Н. В. Визначення циклічних залежностей в економіці України на основі аналізу окремих макроекономічних показників [Електронний ресурс] / Н. В. Юдіна // Економічний вісник Національного технічного університету України «КПІ». 2016. - №13 - Режим доступу : http://ev.fmm.kpi.ua/article/view/80084.

2. Юдіна Н. В. «Дорожня карта» підприємства у контексті футурології техногенної економіки. Традиції і інновації. [Електронний ресурс] / Н. В. Юдіна // Інновації та фундаментальні науки в умовах техногенної економіки : зб. матеріалів міждисциплінар. наук.-практ. конф., Київ, 25 листоп. 2016 р. / [уклад. Л. І. Юдіна]. К., 2016. - Режим доступу : http://futurolog.com.ua/publish/2/Zbirnyk.pdf\#page=6. ISBN 978-966-97581-1-8.

3. Митченко Т. Е. Основные пути повышения эффективности удаления гуминовых веществ из воды методом ультрафильтрации // Т. Е. Митченко, Е. М. Светлейшая / Науково-технічні вісті. - №3(5), 2011 - с. 16-31.

4. Пат. 2240857 Украина, МПК В01D39/00, В01J20/28, B01J20/26. Фильтрующая загрузка для комплексной очистки воды / Митченко Т.Е. (UA), Митченко А.А. (UA); заявитель и патентообладатель Митченко Т.Е. - № 2002108675/15; Заявл. 05.04.2002; опубл. 27.11.2004

5. Мітченко А. О. Вдосконалення сорбційних технологій видалення гумінових речовин із води для раціонального використання водних ресурсів Автореф. дис... канд. техн. наук: 21.06.01 / А.О. Мітченко; НАН України. Ін-т колоїд. хімії та хімії води ім. А.В.Думанського. - К., 2004. - 20 с. — укр.]. 